\title{
BENJAMIN PÉRET: UM SURREALISTA NO BRASIL (1929-1931) *
}

Jean Puyade

Resumo: Depois de retratar a trajetória humana, intelectual e poética de Benjamin Péret até 1928, o artigo se debruça sobre o que constitui o seu objeto - as relações do poeta francês com o Brasil até 1931: casamento com a cantora lírica carioca Elsie Houston, encontro com Mário Pedrosa, vinda ao Brasil, recepção do casal pela Revista de Antropofagia (com interessante destaque para o surrealista francês), militância política, escritos sobre o Brasil, nascimento de seu filho e expulsão do Brasil após prisão pela polícia política de Getúlio Vargas.

Palavras-chave: PÉRET (Benjamin); surrealismo; poesia; Antropofagia; Brasil; História do Brasil; Século 20.

Résumé: Cet article commence par situer la trajectoire humaine, intellectuelle et poétique de Bejamin Péret jusqu'en 1928, puis il se penche sur son objet central d'étude - les rapports du poète français avec le Brésil jusqu'en 1931: mariage avec la cantatrice brésilienne Elsie Houston, premiers contacts avec Mário Pedrosa, venue au Brésil où Elsie et lui sont accueillis avec enthousiasme par la Revista de Antropofagia (qui montre un intérêt particulier pour le surréaliste français), militantisme politique, écrits sur le Brésil, naissance de leur fils et, finalement, expulsion du Brésil suite à sa détention par la police politique du gouvernement de Gétulio Vargas.

Mots clés: PÉRET (Benjamin); surréalisme; poésie; Anthropophagie; Brésil; Histoire du Brésil; XXe siècle.

Quando o poeta francês Benjamin Péret chega no Brasil, em fevereiro de 1929, tem 30 anos de idade e quase dez anos de atividade no seio do grupo que fundou o surrealismo. Trata-se de um homem com uma trajetória e um pensamento já conformados, arraigados numa experiência juvenil determinante para o curso de sua vida. Posteriormente, a um questionário que perguntará: “Estréia na vida?”, responderá ironicamente: “A Guerra de 1914, o que facilitou tudo!"1

Péret faz parte da jovem geração que sobreviveu à primeira maior carnificina dos tempos modernos, após sofrer na própria carne o autoritarismo obtuso do exército francês, no qual sua mãe obrigou-o a se alistar na véspera da guerra. $\mathrm{O}$ abalo moral provocado em Péret, bem como em outros de sua geração, pelo que consideram ser a manifestação da falência moral e histórica da ordem ocidental, desencadeará nele uma revolta absoluta, que guardará intacta até o fim de sua vida, com uma capacidade especial de renúncia e de denúncia. $\mathrm{O}$ homem que desembarca no Rio, em 1929, está engajado numa aventura cujo ponto de partida é uma convicção arraigada: é inaceitável a ordem social, moral, intelectual e artística que legitimou, mesmo que parcialmente, a barbárie na qual uma parte da humanidade desapareceu. Desse homem — do qual Paul Éluard dirá: "Quem é Benjamin Péret? Um homem que parece um homem" - esta convicção fez um homem intransigente. Mas também um homem aberto, disponível a tudo que permitisse encontrar uma saída.

Esse poeta - que, fiel aos seus engajamentos juvenis até o fim de sua vida,

\footnotetext{
* Versão - revista, corrigida e ampliada - de palestra proferida em diversas ocasiões no Brasil e na Argentina. Este texto encontrou dois pontos de partida: em "Je ne mange pas de ce pain-là" de Sergio Lima (A Phala, n. 1. São Paulo: FAAP, ago. 1967. p. 115-130) e em notas inéditas de Luis Antonio Novaes.

${ }^{1}$ PÉRET, Benjamin. Resposta ao questionário para o Nouveau Dictionnaire des contemporains (Novo dicionário dos contemporâneos). O questionário e as respostas de Péret estão reproduzidos in: PÉRET. Amor sublime (Ensaio e poesia). Org. Jean Puyade. Trad. Sérgio Lima, Pierre Clemens. São Paulo: Brasiliense, 1985. p. 200.
} 
permanecerá, junto com André Breton, o último membro do núcleo histórico a impulsionar o movimento surrealista - não hesitará, em 1944, em propor ao mesmo Breton o abandono da sigla surrealismo, tal seu temor de que o conservantismo dos epígonos desfigurasse e fossilizasse o movimento. Já em 1922, Péret havia manifestado a mesma disponibilidade e tinha sido um dos primeiros a chamar à ruptura com Dadá. Algumas semanas após a publicação do texto de Breton intitulado "Larguem tudo", escrevia um outro apelo, também publicado na revista Littérature:

"Dadá morreu, Dadá morreu, Dadá morreu.

Dadá se propunha a destruir mas ele próprio se desagregou antes que sua ação se fizesse sentir.

$[\ldots]$

Abandono os óculos Dadá e, pronto para ir embora, olho de onde vem o vento sem me preocupar em saber o que será nem onde levará.

Amanhã, estarei ainda pronto a pegar carona no carro de meu vizinho, caso ele se disponha a tomar uma outra direção do que a minha."2

Sete anos depois, no momento em que se defronta com um país novo, com um mundo diferente, é importante apreciar a disponibilidade de Péret: sem ser um eclético ou um nômade profissional, não está disposto a ficar preso a padrões que impediriam sua movimentação. Se decidiu partir para o Brasil - quando os surrealistas estão engajados numa luta interna determinante que desembocará, no final de 1929, na proclamação do Segundo manifesto do surrealismo - , é porque aquilo que o impele a esse país é muito forte. Efetivamente, durante aqueles três anos de estada no Brasil, Péret abrir-se-á à essa nova experiência. Entretanto, para compreender por que, ao final desse período, continuará num relativo isolamento intelectual e artístico, apesar dos numerosos contatos com os modernistas, é necessário precisar alguns traços de seu itinerário e de sua personalidade.

\section{“POETA, ISTO É, REVOLUCIONÁRIO"3}

É em 1920 que Péret encontra em Paris o núcleo que fundará o surrealismo: André Breton, Louis Aragon, Philippe Soupault e Paul Éluard, reagrupados em torno de Littérature, reunidos pela mesma revolta e seduzidos pelo projeto dadaísta de destruição de todos os valores tradicionais. Nesse grupo, o que caracteriza Péret?

É um dos mais radicais na vontade de unir a ação e a palavra, de unificar sua vida num engajamento total. Assim, em 1921, por ocasião do julgamento de Barrès ${ }^{4}$, Péret escolhe o papel mais provocador. Aparece vestido com a farda francesa, representando o "soldado desconhecido", símbolo de todos os militares franceses desaparecidos durante a Primeira Guerra Mundial e mito da França vitoriosa na mesma. Mas esse soldado desconhecido desfila com passo de ganso e fala alemão. Imperturbável diante dos gritos de ódio do público, Péret atinge, assim, os valores que denunciará durante toda a sua vida. Completa, à sua maneira, o ato de acusação contra Barrès, redigido e lido por André Breton por ocasião do julgamento. Desta forma, ambos centram seu ataque naquilo que, para eles, constitui um obstáculo à progressão revolucionária do espírito, já se diferenciando do gênero de negação cega e

\footnotetext{
2 Idem. “À travers mes yeux”, 1922. Citado por BÉDOUIN, Jean-Louis. Benjamin Péret. Paris: Seghers, 1961. Coll. "Poètes d'aujourd'hui". p. 31-32.

${ }^{3}$ Idem. Le Déshonneur des poètes. (México, 1945). Paris: José Corti/ACTUAL, 1986. p. 14.

${ }^{4} \mathrm{O}$ julgamento de Barrès foi um tribunal simulado promovido em 13 de maio de 1921, em Paris, pelo movimento Dadá a partir de uma proposta de André Breton e Louis Aragon. O acusado, o francês Maurice Barrès (1862-1923), fora autor de romances que Breton e Aragon tinham valorizado por sua pregação de uma nova maneira de pensar baseada na liberdade e no individualismo. Posteriormente, Barrès tinha participado da campanha anti-semita contra Dreyfus e se destacado pelo seu ultranacionalismo, seu patriotismo revanchista contra a Alemanha e sua defesa exacerbada da Primeira Guerra Mundial. Em Entretiens (1913-1952), Breton explicou que "a questão [do caso Barrès] é saber em que medida pode ser considerado culpado um homem que a sede de poder levou a tornar-se campeão de idéias conformistas completamente opostas às de sua juventude".
} 
nihilista de Dadá. No registro do humor violento e do sarcasmo escabroso, isto representa para Péret como que um ensaio teatral do enfrentamento ideológico e poético no qual vai lançar-se com toda sua vitalidade e radicalidade.

Após a ruptura com Dadá, Péret torna-se diretor da revista do grupo: La Révolution surréaliste ( A Revolução Surrealista). Breton justifica assim a escolha:

"No início, a ênfase da revista está colocada sobre o surrealismo puro - o surrealismo, digamos, em estado nativo - , motivo pelo qual sua direção é confiada a Pierre Naville e Benjamin Péret, que podem ser então considerados como os mais integralmente animados do novo espírito e os mais rebeldes à qualquer concessão."

Péret participa com todas as suas forças à vida do grupo surrealista, forma de atividade coletiva que os surrealistas sempre sustentaram ser, de longe, superior à qualquer outra. Engaja-se, sem restrições, na prática sistemática da "escritura automática", demonstrando uma aptidão mais desenvolvida que muitos de seus amigos em desligar as conexões alimentadoras dos circuitos do pensamento dirigido, no sentido de permitir a manifestação do "funcionamento real do pensamento" com mais liberdade. O crítico Jean-Christophe Bailly observa:

"Oferecendo a menor resistência possível à escritura automática e à completa honestidade que ela implica, Benjamin Péret terá sido o maior fator de aceleração mental no movimento surrealista.",

Claro, ele não se recusa em utilizar formas de expressão e de ação conscientes e refletidas, mas essas são apenas o indispensável complemento ao caráter profundamente irracional de sua poesia. Segundo o professor Ferdinand Alquié,

"É dedicando-se a criar uma poesia objetivamente não interpretável que o surrealismo trouxe à tona a essência de toda a poesia. Com suas imagens evidentes e desprovidas de sentido lógico, imagens que desencorajam toda e qualquer explicação de estilo racional ou escolar, Benjamin Péret desempenhou nessa purificação um papel essencial.",

Uma voz e um mundo afirmam-se através dos poemas e contos publicados até a véspera de sua partida para o Brasil ${ }^{8}$. Posteriormente, Buñuel e Dali explicarão a importância que essa poesia teve para eles, em 1928-1929, quando Péret, então no Brasil, não os havia ainda encontrado. Nas palavras de Buñuel, ele

"era o poeta surrealista por excelência: liberdade total de uma inspiração límpida, fluindo como fonte, sem nenhum esforço cultural e no mesmo instante recriando um outro mundo." 9

Nos seus poemas como nos seus contos aparece o mesmo jorro de imagens, a mesma ausência de premeditação. Evocam o estado de desligamento do sonho e aproximam-se das histórias contadas com voz doce por Péret durante a fase dos sonos hipnóticos. Daí o traço que, a partir de 1929, domina a obra de Péret: sua analogia com o mundo primitivo, o mundo de antes do "pecado original", da época em que se enraízam os mitos, época na qual o extraordinário era a

\footnotetext{
5 BRETON, André. "Entretien radiophonique avec André Parinaud, no 8”. In: Idem. Entretiens (1913-1952). (1952). Nouvelle édition, revue et corrigée. Paris: Gallimard, 1969, coll. "Idées". p. 110.

${ }^{6}$ BAILLY, Jean-Christophe. Au-delà du langage. Paris: Éric Losfeld. Coll. "Le Désordre”, 1971.

7 ALQUIÉ, Ferdinand. Philosophie du surréalisme. Paris: Flammarion, 1955. Coll. "Nouvelle Bibliothèque scientifique".

${ }^{8}$ Poemas e contos de Benjamin Péret publicados antes de sua viagem ao Brasil: Le Passager du Transatlantique (O passageiro do transatlântico, 1921), ilustrado por Hans Arp; Au 125 du boulevard Saint-Germain (No 125 do bulevar Saint-Germain, 1923), ilustrado por Max Ernst; Immortelle maladie (Doença imortal, 1924), ilustrado por Man Ray; Il était une boulangère (Era uma vez uma padeira, 1925); 125 proverbes mis au goût du jour (125 provérbios adaptados ao gosto do dia), escrito em colaboração com Éluard: Dormir, Dormir dans les pierres (Dormir, dormir nas pedras, 1927), ilustrado por Yves Tanguy; Le Grand Jeu (O grande jogo, 1929); Et les seins mouraient (Os seios morriam, 1928), ilustrado por Miró.

${ }^{9}$ BUÑUEL, Luis. Mon Dernier Soupir. Paris, Robert Laffont, 1982. Coll. "Ramsay-Poche-Cinéma”. p. 133.
} 
regra. É em sintonia com os narradores primitivos que o poeta francês expressa-se, mesmo se seu mundo não evoca espíritos de cuja boa vontade dependeria nossa sobrevivência. Mas, para ele, o ato poético tem a mesma gravidade, produto de uma trajetória visando à restituição dos poderes perdidos, dos quais o homem foi espoliado, durante séculos, pelo racionalismo estreito e pelos tabus religiosos e sociais. Tudo isto inscreve-se na vontade de mudar a vida, que é o móvel do grupo surrealista.

Mudar a vida, mas também transformar o mundo: Péret pesará na guinada rumo ao engajamento político do grupo a partir do verão de 1925. Claro, a necessidade de uma mudança econômica e social que colocasse um fim às injustiças gritantes jamais foi dissolvida na reivindicação surrealista, por mais absoluta que fosse no início; mas é a partir de 1925 que os surrealistas dedicam, de maneira sistemática, sua atenção à descoberta dos meios através dos quais tal transformação pode ser efetivada. Neste sentido, Péret participa na elaboração dos manifestos que marcam o engajamento dos surrealistas em prol da revolução social e em defesa da Revolução Russa, numa trajetória que vai da colaboração com os animadores da revista Clarté (um grupo de intelectuais simpatizantes do comunismo) até a entrada no Partido Comunista Francês - PCF, onde o domínio da burocracia stalinista não é ainda definitivo ${ }^{10}$. Nesta atuação, expressa-se a vontade dos surrealistas em evitar um abstencionismo social que poderia reconduzir o surrealismo a um plano meramente literário e artístico, mesmo se, para além da condição social, sua grande preocupação continue sendo a condição humana. Embora prontos a utilizar "martelos materiais" para quebrar a escravidão na qual uma parte ínfima do gênero humano subjuga a outra, nem por isto abandonam a reivindicação e a atividade surrealistas no que elas têm de específico. Péret permanecerá um poeta e um militante revolucionário até o fim de sua vida, sem jamais misturar os dois planos de atividade.

\section{PÉRET E ELSIE HOUSTON}

Em 1928, Péret casa-se, na França, com Elsie Houston, cantora lírica brasileira, exímia intérprete de Villa-Lobos. Elsie é filha de Dona Arinda, carioca, separada de um dentista norte-americano, o doutor Houston, com quem tinha casado no Rio. Conforme Antonio Bento,

"Na casa de dona Arinda Houston, onde se reunia um grupo de intelectuais e artistas adeptos dos modernos, havia também um ambiente de simpatia e interesse pela pintura de Ismael [Nery], graças ao espírito aberto daquela senhora e de suas filhas, Celina Veloso Borges, Mary Houston Pedrosa e Elsie Houston. Aliás, esta cantora, que possuía uma voz de timbre inesquecível, incluía em seu repertório peças modernas, tendo se tornado, mais tarde, uma recitalista de câmara de renome internacional."11

Com efeito, a irmã de Elsie, Mary, casou-se com Mário Pedrosa, um jovem advogado e jornalista, que, junto com seu amigo Lívio Xavier, entrou em 1926 no Partido Comunista Brasileiro. Formados pelo historiador e professor da faculdade de direito do Rio, Edgardo Castro de Rebelo, que os orientou em direção ao marxismo, leitores das revistas Clarté e La Révolution surréaliste, suportam mal a atmosfera provinciana e reacionária do fim da Velha República. Cartas trocadas entre Mário Pedrosa e Lívio Xavier, publicadas pelo professor José Castilho Marques Neto, mostram dois jovens desejosos de escapar a dois perigos: aquele "de fazer da Revolução um ideal abstrato, longínqüo, transcendental, no plano do espírito,

\footnotetext{
${ }^{10}$ Engajando-se com toda a radicalidade, Péret adere ao PCF em 1927 (com Breton, Aragon, Éluard e Unik) onde, sem descuidar de suas tarefas surrealistas, é militante e crítico de cinema, em L'Humanité, jornal daquele partido. Péret será rapidamente sensível ao processo de stalinização e começará, antes que os seus companheiros, a dirigir-se para a luta da "oposição de esquerda" e a tornar-se um intransigente e encarniçado adversário do stalinismo.

11 BENTO, Antonio. "O ambiente no Rio ao tempo de Ismael Nery". Cadernos Brasileiros, n” 35 . Rio de Janeiro, 1966. Nesta citação, assim como nas demais da época, utiliza-se a grafia atual.
} 
exclusivamente, [...], um idealismozinho vagabundo como outro qualquer, capaz de contentar cérebros almofadinhas e [ilegível no texto original] de poetas pequeno-burgueses"; por outro lado, o perigo do "otimismo necessário, a limitação intelectual", sobre a qual escreveu Pedrosa, "eis onde não posso chegar" ${ }^{12}$. Sabe-se, aliás, por Antonio Bento, que Mário Pedrosa teria tido o projeto, com Lívio Xavier e com o próprio A. Bento, de "lançar um manifesto, mais ou menos dentro do espírito do surrealismo" nos primeiros meses de $1926^{13}$.

Em 1928, Pedrosa, enviado a Moscou para seguir a escola de quadros da Internacional Comunista, convenceu-se, em Berlim - onde teve que interromper sua viagem por razões de saúde - que o processo de degenerescência da direção do Partido Comunista Russo, sob a direção de Stalin, exigia que se unisse à luta da Oposição Internacional de Esquerda dirigida por Trotski. Pedrosa entra em contato com Pierre Naville, um ex-surrealista que se tornara um dos quadros da corrente trotskista. É nesse momento que Mário Pedrosa e Benjamin Péret se encontram e se conhecem.

Esse encontro contribuirá para a evolução política de Péret. Segundo Pierre Naville, em entrevista que nos concedeu em 1985, Péret teria manifestado, na véspera de sua partida para o Brasil, a vontade de concretizar um contato com ele, então representante de Trotski na Europa. Em todo o caso, entrando na família Houston, Péret encontra um meio propício ao prosseguimento de sua reflexão tanto no terreno poético como naquele da ação social. Por seu lado, Elsie Houston, em ligação com Villa-Lobos e Mário de Andrade, desenvolve pesquisas sobre as canções populares brasileiras, sobre as influências indígena e africana nessa arte. Inclusive, Elsie escreve e publica um livro em francês sobre o tema: Canções populares do Brasil, editado pela livraria orientalista Paul Geuthner. O interesse pela arte e pensamento primitivos foi, sem dúvida nenhuma, um elemento determinante para impulsionar Péret e Elsie a viajarem para o Brasil. Não esqueçamos o irresistível apelo exercido pelas "artes selvagens" sobre os poetas e pintores surrealistas, uma vez que "desnudam as raízes da criação artística e, conseqüentemente, contribuem de uma maneira decisiva, à definição ou à verificação dos modos de intervenção do surrealismo nas artes plásticas"14 e na poesia. Entre 1926 e 1928, as exposições dos pintores surrealistas foram acompanhadas de exposições de objetos das ilhas da Oceânia ou dos índios da Colômbia britânica, do Novo México, da Colômbia e do Peru.

Entretanto, a arte primitiva do Brasil é inteiramente desconhecida para eles. Péret deseja, sem nenhuma dúvida, abrir um novo caminho de conhecimento. Tal perspectiva vinculada ao acordo político que se esboça entre Péret e Pedrosa e ao amor intenso que reúne Benjamin e Elsie - afasta-o, portanto, fisicamente, do grupo surrealista no momento preciso em que este está engajado nos embates que desembocarão, em 1929, no Segundo manifesto do surrealismo.

Uma carta de Péret, datada de 5 de dezembro de 1928 e dirigida a A. Guinle, rico mecenas carioca, o comprova: ele pede um financiamento para uma viagem ao Brasil, com os seguintes objetivos: "1) busca e compra de objetos pré-colombianos; 2) realização de um filme documentário e de um filme romanceado sobre as lendas e costumes dos índios; 3) artigos para publicação no Petit Journal [do qual Péret é repórter] assim como projeto de um livro; 4) coleção de cantos e músicas populares indígenas." ${ }^{15} \mathrm{O}$ itinerário projetado lhe faria percorrer a Amazônia, o Peru (Iquitos, Lima, as costas peruanas, Cuzco), o norte da Bolívia, o Mato Grosso (Goiás) e, enfim, o rio Araguaia até o mar. Guinle recusará financiar a viagem, apesar de se propor a facilitar os passos e esforços do poeta francês.

\footnotetext{
${ }^{12}$ As cartas de Mário Pedrosa a Lívio Xavier foram publicadas em Leia, n. 140. São Paulo, junho de 1990, p. 3336, com apresentação de José Castilhos Marques Neto.

${ }^{13}$ BENTO, art. cit.

${ }^{14}$ PIERRE, José. André Breton et la peinture. Lausanne (Suisse). L’Âge d’Homme, 1986. Coll. "Cahiers des avant-gardes".

${ }^{15}$ Carta de Péret à A. Guinle, de 5 de dezembro de 1928. Encontra-se na seção "Péret" do Arquivo Lívio Xavier (CEMAP, São Paulo). O inventário da seção "Péret" foi realizado por Miriam Fragoso Xavier e Jean Puyade, para o CEMAP (SP) e a ACTUAL (Paris, França).
} 
Muitas cartas de Péret evidenciam a seriedade com a qual encara esses objetivos. Assim, confirma-se um interesse que vai ocupá-lo até o fim de sua vida e que suas estadas no Brasil e no México reforçarão. O livro, do qual ele fala desde 1928 enquanto um projeto, será terminado em 1959, algumas semanas antes de sua morte e publicado postumamente na França, pela editora Albin Michel, em 1960, com o título Antologia dos mitos, lendas e contos populares da América. Não há nenhuma dúvida que suas discussões, já em 1928, com Elsie, Villa-Lobos e Pedrosa sobre esse assunto, fazem-lhe pressentir o parentesco de sua obra e dessas artes.

Péret embarcará com Elsie no início do ano de 1929, munido de mais de dez cartas de recomendação escritas e assinadas por Villa-Lobos, nas quais é descrito como "um talentoso escritor, poeta e jornalista francês" e Elsie como "uma admirável cantora, primogênita de nossa nova raça brasileira, genuína em físico, alma e espírito"; ambos são apresentados como desejosos de "conhecer o coração dos vários estados do Brasil". São cartas dirigidas para todas as pessoas que podem facilitar sua viagem de estudos na Amazônia, no Mato Grosso e no norte do Brasil e, também, para todos os diretores de jornais do Rio e de São Paulo e alguns da Paraíba. Villa-Lobos deseja que os dois sejam bem recebidos, "à brasileira", pela imprensa nacional. ${ }^{16}$

\section{PÉRET NO BRASIL: 1929-1931}

Péret e Elsie desembarcam no Brasil na primeira quinzena de fevereiro de 1929. Sua chegada recebe uma boa cobertura da imprensa.

Frente à confusão e ignorância vigentes em relação à compreensão do surrealismo, Péret opta por uma tática inicial de esclarecimento, visando a explicar, por exemplo, numa entrevista publicada no Correio da Manhã, que

"o surrealismo não é nem o supra-realismo como é corrente denominá-lo aqui, nem um realismo mais acusado, como aquele de Zola. É um realismo espiritual que não admite a separação do valor moral da personalidade individual."

Ao mesmo tempo, mostra a importância e contribuição da obra de Freud para o surrealismo, salientando que é uma das fontes, das bases do surrealismo. Explica também que o surrealismo

"repousa sobre a crença numa realidade superior de certas formas de associações até então negligenciadas, na onipotência dos sonhos, no jogo desinteressado do pensamento. Ele tende a arruinar definitivamente todos os mecanismos psíquicos e a substituí-los na resolução dos principais problemas da vida." $" 17$

Cita a definição do surrealismo como "automático psíquico puro" (primeiro Manifesto de Breton) e refere-se à pintura de Joan Miró e de Giorgio de Chirico como as mais representativas do movimento. Em sua viagem a São Paulo, em março, em vários jornais (como por exemplo, o Diário de São Paulo, o Correio Paulistano), e em particular na sua famosa conferência, "O espírito moderno: do simbolismo ao surrealismo", proferida em 18 de março no salão vermelho do Hotel Esplanada, irá sentir novamente a necessidade de precisar sua definição, diferenciando-se dos simbolistas, em particular de Mallarmé e Valéry, poetas em quem "a arte, segundo o ponto de vista extremado deles, anula sua relação com a vida." Péret destaca a dívida do surrealismo para com Apollinaire e o cubismo, para com o humor em particular e para com a inspiração que ocupa um lugar de destaque durante o período da guerra e aquele anterior à mesma. Tal conferência e todo esse trabalho de esclarecimento permitirão, a partir de seu contato com o movimento antropófago, uma clarificação, uma matização por parte do grupo de Oswald de Andrade em relação ao surrealismo.

A Revista de Antropofagia saúda a chegada de Péret nos seguintes termos:

\footnotetext{
${ }^{16}$ Cartas de Villa-Lobos. Encontram-se na seção "Péret" do Arquivo Lívio Xavier (CEMAP, SP).

${ }^{17}$ Correio da Manhã, Rio de Janeiro, 21 de fevereiro de 1929.
} 
"Não nos esqueçamos que o surrealismo é um dos melhores movimentos préantropofágicos. A liberação do homem como tal, através do ditado do inconsciente e de turbulentas manifestações pessoais, foi sem dúvida, um dos mais empolgantes espetáculos para qualquer coração de antropófago que nestes últimos anos tenha acompanhado o desespero do civilizado. [...]. Nunca antes soprara tão alto o desespero final dos cristianizados.

Depois do surrealismo, só a antropofagia.

Benjamin Péret [...] é um antropófago que merece cauins de cacique." ${ }^{18}$

O número seguinte da revista saúda a conferência de Péret: "Foi uma lição. O ocidente que nos tem mandado tanta coisa ruim, desta vez nos enviou uma exceção. Péret trouxe a magnífica coragem de uma liberdade." 19

Naquele mesmo momento, desenvolve-se uma polêmica pública entre Péret e o crítico de arte Raul de Polillo, nas páginas do Diário de São Paulo. Os títulos dos artigos dão uma idéia dos preconceitos enfrentados por Péret:

- Raul de Polillo: "Que é super-realismo? Uma entrevista com o Sr. Péret, em que não se disse nada de mais e de menos, mas que deve ser lida" (02.03.1929);

- Raul de Polillo: "O super-realismo não é coisa alguma. Vagas considerações lógicas em torno de uma teoria literária que ninguém encara com seriedade" (05.03.1929);

- Benjamin Péret: “O que é o surrealismo. Resposta a um imbecil” (07.03.1929);

- Benjamin Péret: “Onde estás?” (14.03.1929);

- Raul de Polillo:"'Os aventureiros da literatura. Paris é a rua 25 de março das Artes e das Ciências Universais" (21.03.1929);

- Benjamin Péret: "Pequeno panorama da pintura moderna" (27.03.1929).

Com efeito, Péret e Elsie chegam ao Brasil num momento bem particular, em que agoniza o sistema político da Velha República, cujos limites foram denunciados no terreno estético pelos artistas modernistas de 1922 (ano que também testemunha o início do movimento tenentista e a fundação do Partido Comunista Brasileiro); o casal chega no último período de vida desse regime, numa situação em que, no terreno da arte, os modernistas conhecem, entre si, uma fase de diferenciação muito profunda. O movimento mais radical a Antropofagia, de Oswald - está envolvido numa tarefa de denúncia e superação do caráter limitado dos objetivos anteriormente traçados pelo próprio Oswald no seu Manifesto da poesia Pau-Brasil (1924), objetivos que podem ser resumidos nos seguintes termos:

"Incorporados ao nosso meio, à nossa vida, é dever tirar dos recursos imensos do país, dos tesouros de cor, de luz de bastidores que os circundam, a nossa arte que se afirma, ao lado de nosso intenso trabalho material de construção de cidades e desbraçamento de terras, uma manifestação superior de nacionalidade."

A partir desse retorno ao genuinamente brasileiro (depois da denúncia da poesia da Colônia que importava e imitava toda a arte da Europa), Oswald começa a denunciar uma arte que se limita a registrar a realidade brasileira sem criticá-la, um flagrante fixado, embora nativista, uma atitude esteticista por excelência. Para isto, utiliza a Revista de Antropofagia que fazia junto com Mário de Andrade, num momento em que tentará ampliar a diferenciação. Há testemunhas, em particular Geraldo Ferraz, de que a presença de Benjamin Péret entre os antropófagos foi um elemento chave para impulsionar aquela diferenciação. Após ter evocado suas lembranças da chegada de Péret e Elsie Houston em São Paulo, Geraldo Ferraz explica:

"Foi por aí que a Revista de Antropofagia cessou sua publicação. As dissidências que fermentavam dentro do grupo inicial, e que tinham

\footnotetext{
${ }^{18}$ CUNHAhMBeBinHO. "Péret". Revista de Antropofagia, $2^{\mathrm{a}}$ dentição, $\mathrm{n}^{\circ}$ 1. In: Diário de São Paulo, 17.03.1929.

${ }^{19}$ SEM AUTOR. "A conferência de Péret”. Revista de Antropofagia, $2^{\mathrm{a}}$ dentição, no 2. In: Diário de São Paulo, 24.03.1929.
} 
transformado aquele veículo de combate e criação num repositório de literaturas de todo jeito, não dariam mesmo longa vida à publicação [...]. Passamos todos algumas semanas de expectativa [...]. Oswald de Andrade reunira, em torno de si, além de Tarsila, Raul Bopp, Jaime Adour de Câmara, Clóvis Gusmão, Nélson Tabajara, Osvaldo Costa, e a aquisição mais recente da Antropofagia, o poeta surrealista Benjamin Péret [...]. Ainda não se declarara a cisão, mas pouco tempo depois ela se concretizaria. Os fatos se precipitariam, com a tomada de posição de Benjamin Péret, de que recebi o livro Et les seins mouraient, dedicado a Elsie."20

Como se sabe, a publicação, em 17 de março, do primeiro número da "2a dentição" da Revista de Antropofagia, dirigida por Oswald coincide com o início da estada de Péret no Brasil.

A diferenciação será tal entre os antropófagos que Carlos Drummond de Andrade rompe com Oswald porque o movimento "ainda não jantou o Benjamin Péret"21. Isto é, Drummond estima que a presença de Péret foi um elemento intragável, o que o leva à ruptura com o caminho tomado pela Revista. Benedito Nunes é quem melhor analisa esse momento particular do grupo de antropófagos, quando este recebe o pleno impacto da influência surrealista:

"[...] considerando que o alvo dos tiros era a sociedade, a moral convencional, o casamento monogâmico, a dominação política da Igreja, a desigualdade social, podemos afirmar que o emprego das armas utilizadas tinha muito mais do calor revolucionário surrealista do que da confusão dadaísta que não queria dizer nada e que não queria fazer nada." ${ }^{22}$

Mas a situação é contraditória. Não esqueçamos que, em 1929, Oswald pertence ainda ao partido de Washington Luis, o PRP, e que fará campanha pela eleição de Júlio Prestes; também, no congresso dos cafeicultores, defenderá publicamente a política do governo de Washington Luis. A Revista de Antropofagia publica alguns breves encartes de citações de Marx (talvez sob influência de Péret), mas, ao mesmo tempo, apresenta "a viagem filosófica do conde Keyserling", em julho de 1929, como "outro grande acontecimento", de igual importância e no mesmo plano que a próxima (e primeira) exposição de Tarsila no Rio de Janeiro: “[...] Keyserling é o grandioso desespero ocidental e a ânsia de renovamento de que só a América natural possui a chave" ${ }^{, 23}$. No mesmo momento em que Oswald de Andrade recebe de braços abertos o filósofo alemão, Benjamin Péret escreve um artigo virulento ("Keyserling, filósofo reacionário? — resposta à sua conferência") que tenta publicar na imprensa paulista.

Nesse texto político, um dos primeiros que se conhece de Péret, encontrado nos arquivos de Lívio Xavier, ele critica as posições metafísicas e confusionistas de Keyserling,

\footnotetext{
${ }^{20}$ FERRAZ, Geraldo. Depois de Tudo. Rio de Janeiro: Paz e Terra/São Paulo: Secretaria Municipal de Cultura, 1983. Col. "Depoimentos". p. 43 e 45.

${ }^{21}$ Carta de Carlos Drummond de Andrade. Revista de Antropofagia, $2^{\mathrm{a}}$ dentição, ${ }^{\circ}$ 11. In: Diário de São Paulo, 19.06.1929.

${ }^{22}$ NUNES, Benedito. “Antropofagismo e surrealismo". Remate de Males, n. 6. Campinas: UNICAMP, junho de 1986. p.24. Esse artigo está reproduzido no presente livro.

Uma das manifestações de simpatia em favor do surrealismo por parte dos antropófagos exprime-se claramente no breve encarte aparecido na Revista de Antropofagia, $2^{\mathrm{a}}$ dentição, n. 13 (Diário de São Paulo, 04.07.1929):

"O poeta empastelado Menotti del Piccolo continua irremediavelmente analfabeto. Supõe que todo nome francês tem Le na frente. É assim que em vez do conhecido nome de André Breton, ele escreve Le Breton! Fica mais bonito Le Bossuet, Le Voltaire!

O nosso grande Aníbal Machado interpelado sobre se queria responder as grosserias do chefe do fascio do Bexiga, replicou por telegrama:

'Menotti não conhece o surrealismo.
}

Eu não conheço Menotti.'

${ }^{23}$ SEM AUTOR. "Dois grandes acontecimentos no Brasil: a primeira exposição de Tarsila e a viagem filosófica do conde Keyserling”. Revista de Antropofagia, $2^{a}$ dentição, n. 12. In: Diário de São Paulo, 26.06.1929. 
embora demonstrando um manuseio ainda sumário do marxismo. Nas suas cartas à Elsie, em outubro de 1929, Péret duvida da publicação do artigo na imprensa brasileira "porque está cheirando demais a comunismo"; em seguida, confirma que o artigo foi recusado tanto pelo Correio Paulistano como pelo Diário de São Paulo.

No presente estágio das pesquisas, a ausência de documentos não permite seguir passo a passo as relações de Péret e dos membros do grupo da Revista de Antropofagia (cujo último número será aquele de 01.08.29). Sabe-se que a tentativa de realizar o Congresso de Antropofagia, em outubro de 1929, não será concretizada e que o grupo cessará suas atividades em 1930. Mas, é em torno do verão de 1929 que a atividade e a elaboração comuns, dos antropófagos com Péret, parecem encontrar seus limites.

Não há dúvida que o engajamento político e poético revolucionários de Péret irá dissuadir os antropófagos de avançar mais além com o surrealismo. Para Péret e os surrealistas, não há hiatos entre o poeta e o militante revolucionário. Há indivíduos dirigidos por uma ação poética do espírito tentando reunificar o homem mutilado e dividido. Há a exigência absoluta de uma unidade que engloba a vida cotidiana e a existência social num mesmo projeto de transformação revolucionária do mundo e das relações humanas. Péret e seus amigos cortaram as amarras com o mundo da "literatura", o qual, aceitando a ruptura entre a vida e a obra do escritor, remete esta última ao quadro das estruturas alienadas; vivem na tensão ética da luta pela vitória da revolução social, integrada à sua ação poética e elemento da mesma. O "sucesso", no sentido arrivista do termo, não lhes interessa. Desejam ser os precursores da nova sociedade onde o clima das obras de experimentação e de investigação por eles reclamados será o próprio clima da vida, onde não existirá mais a divisão entre trabalho intelectual e trabalho manual, o antagonismo entre elite artística e massas incultas.

Após a chamada Revolução de 1930, Oswald de Andrade, então casado com Pagú, conhecerá uma evolução, que o levará à adesão, em 1931, ao Partido Comunista Brasileiro, que então vive uma fase ultra sectária (dita do "terceiro período dos partidos comunistas"), quando todo aderente de origem intelectual é tido como suspeito. Numa análise sobre os "surrealismos periféricos", em particular aqueles da América Latina, o professor francês Pierre Rivas explica:

“[...] 1930 marca, como é sabido, em toda parte, o tempo do refluxo, o retorno ao tema, ao realismo, passagem da vanguarda à modernidade. É sobretudo o tempo do confronto entre vanguarda e realismo: populismo socialista, neorealismo, literatura proletária. Este confronto está no coração do Segundo manifesto do surrealismo [...]. A especificidade histórico-política destes países periféricos traduzir-se-á por uma colocação entre parênteses do avanço surrealista. As ditaduras existentes [...] e as urgências sociais irão condenar o artista à uma 'má consciência' ou a uma renúncia. As oposições entre revolta burguesa e revolução social, vanguarda e subdesenvolvimento, engajamento e formalismo, conduzem àquela espécie de 'terrorismo' personificado por Pablo Neruda [...].,24

É o período no qual numerosos artistas aceitam a dependência em relação a seu Estado burguês nacional ou em relação ao Estado burocrático stalinista (a União Soviética), momento em que o espaço por uma arte revolucionária independente deverá ser conquistado a duras penas: à contracorrente, ao preço de um retraimento e de um grande isolamento. ${ }^{25}$

\footnotetext{
${ }^{24}$ RIVAS, Pierre. "Periphérie et marginalité dans les surréalismes d'expression romane: Portugal, Amérique latine". In: Surréalisme périphérique. Actes du colloque "Portugal, Québec. Amérique latine: un surréalisme périphérique?”. Présentés et edités par Luís de Moura Sobral. Montréal (Québec, Canada): Université de Montréal, 1984. p. 14-15.

${ }^{25}$ Será preciso esperar os anos 40 para que esta situação comece a mudar. Pagú — após ter animado, na sua saída das prisões de Getúlio Vargas, no início dos anos 40, no jornal de Mário Pedrosa, Vanguarda Socialista, uma polêmica sistemática contra as teorias e práticas do "realismo socialista" — publicará com Geraldo Ferraz, em 1948, um balanço crítico desse processo que bloqueou uma geração de escritores e artistas brasileiros,
} 
De fato, a via de uma cooperação estreita com uma fração de intelectuais radicais brasileiros fechar-se-á para Benjamin Péret, que se chocará, além disso, com os limites das opções estéticas dos meios de esquerda brasileiros e com a influência esterilizante de um marxismo brasileiro muito marcado pelo positivismo e por um materialismo mecanicista.

No decorrer dos anos 1930 e 1931, Péret lançar-se-á a fundo na atividade política internacionalista. Junto com o grupo dirigido por Mário Pedrosa, Lívio Xavier e Aristides Lobo, será um dos fundadores, em 21 de janeiro de 1931, da Liga Comunista do Brasil, seção brasileira da Oposição Internacional de Esquerda (trotskista), tornando-se Secretário do Comitê da região do Rio de Janeiro, com o pseudônimo de Maurício. ${ }^{26}$

É aqui que intervém um novo mal-entendido. A ação política de Péret, em comum com esses jovens - que, como vimos, tinham tido o desejo de lançar, em 1926, um manifesto inspirado no manifesto surrealista - havia criado para ele um meio de fraternidade militante cujo caráter harmônico manter-se-á até o fim de sua vida, apesar das separações e das divisões políticas uteriores. Mas, um incidente acontecido em 1932 - quando ele já está na França, após sua expulsão do Brasil, no fim de 1931, por Getúlio Vargas, devido à sua ação revolucionária - é revelador do isolamento no qual o poeta surrealista encontrava-se no Brasil (embora seja necessário esperar o resultado do trabalho dos pesquisadores do CEMAP, particularmente do professor José Castilho, sobre o arquivo Lívio Xavier, para precisar as posições de uns e de outros no seio da Liga Comunista Brasileira e esclarecer o contexto no qual se produziu o incidente). Após o seu retorno à França, Péret vê-se frente a uma exigência do líder da Liga Comunista Francesa, Pierre Naville (um ex-surrealista, que havia deixado a atividade surrealista, opondo à mesma sua militância política): esse reclama de Péret uma condenação pública das posições surrealistas, para poder tornar-se membro da seção francesa da Oposição Internacional de Esquerda. Recusando com indignação essas injunções típicas de um "sectarismo stalinista", Péret solicita, numa carta, o testemunho e a solidariedade de seus camaradas brasileiros. Esses, através da voz da Comissão Executiva da Liga Brasileira, ratificam e aprovam as posições de Naville, alinhando-se, assim, com seu sectarismo estreito.

Como explicar tal resposta? Uma conferência, proferida por Mário Pedrosa, em junho de 1933, permite compreendê-lo parcialmente, pela luz que joga sobre o estado de espírito de numerosos militantes brasileiros da Oposição de Esquerda. Aquele que tornar-se-á, mais tarde, no Brasil, o defensor da arte abstrata independente, critica, então, os artistas que, como Picasso,

"são marcados por um latente subjetivismo [...] e tomam como estalão universal a própria personalidade [...]. Impressionistas na interpretação do mundo, estes artistas desumanizam-se, separando-se da sociedade, isto é, dos seus problemas vitais, corrompem-se e idotizam-se, restringindo o seu plano social e as suas preocupações estéticas a um puro jogo pueril de formas e naturezas mortas. [...] o campo artístico está dividido estética e socialmente: de um lado, a arte desses criadores [...] desligados completamente da sociedade, em parte por estreiteza mental, em parte para não tomar uma atitude em frente à implacável batalha das duas classes inimigas [...] eles se estiolam num irrespirável individualismo egocentrista a serviço de uma casta parasitária ou no hermetismo diletante para meia dúzia de iniciados [...]. No outro lado, colocam-se os artistas sociais, aqueles que se aproximam do proletariado [...]. É o que explica o realismo do proletariado e dos artistas que o exprimem. [...].

derivação, no terreno da expressão artística, da tragédia que o ascenço e a influência hegemônica do stalinismo representaram para a luta pela emancipação do espírito e do homem em escala mundial.

${ }^{26}$ Dainis Karepovs e Fulvio Abramo, do CEMAP, descreveram esta atividade em "Benjamin Péret, poète révolutionnaire au Brésil" (Traduit du portugais par J. Puyade et G. Prévan. Cahiers Léon Trotsky, $\mathrm{n}^{\circ} 25$. Grenoble: Institut Léon Trotsky, mars 1986. p. 65-80), completado pelo artigo de Karepovs, "Um audacioso indesejável" (D.O. Leitura, n.s., $\mathrm{n}^{\circ} 7$ [antiga série: $\mathrm{n}^{\circ}$ 81]. São Paulo: Governo do Estado de São Paulo, fev. 1989. p. 5). 
É uma arte partidária e tendenciosa. Mas que assombrosa universalização! É que, representando a expressão social da nova classe [...], o que ela espira é um novo humanismo superior, um autêntico e novo classicismo surgido dramática e espontaneamente da própria vida." 27

Tais posições, de um materialismo vulgar, determinista e objetivista, estão bem longe daquelas dos surrealistas que reivindicam, com força, os direitos da subjetividade criadora. Estão longe também das reflexões de Trotski que, em Literatura e revolução, defende as aquisições universais da cultura, opõe-se à noção de cultura proletária e exige que a arte seja, antes de mais nada, julgada segundo suas próprias leis. Sabe-se que essas duas trajetórias paralelas reunir-se-ão no manifesto Por uma arte revolucionária independente (1938), no qual os autores, Breton e Trotski, reivindicarão "Toda licença em arte. [...] para a criação intelectual, [a revolução] deve, já desde o começo, estabelecer e assegurar um regime anarquista de liberdade individual. ${ }^{, 28}$ Para o surrealista e para o dirigente revolucionário, o processo de criação intelectual, artística ou científica, geralmente subjetivo e individual, é realizado segundo leis específicas que não podem sofrer nenhuma pressão exterior, toda criação artística autêntica sendo um ato de protesto contra as condições impostas ao homem no mundo atual. Ambos opõem-se a uma "literatura de propaganda", sem deixar, entretanto, de considerar que a arte não deve se refugiar numa torre de marfim, mas, ao contrário, exprimir o conteúdo latente de uma época, girar em torno do "eixo invisível" da revolução.

Claro, mais tarde, no início dos anos 40, Mário Pedrosa fará seus os termos do manifesto de 1938, que publicará no seu jornal. Mas o que importa para o período que nos interessa é que suas posições refletem os preconceitos dos militantes com os quais Péret mantém, no Brasil, no seio do mesmo partido, relações bastante estreitas, o que permite entender, em parte, portanto, a incompreensão com as quais defrontar-se-á durante a sua estada. Pois, Péret mantém intacta sua atividade surrealista ao longo de sua permanência no Brasil. Ao mesmo tempo em que colabora na revista parisiense ${ }^{29}$, interessa-se de perto pelos trabalhos do Dr. Osorio Cesar sobre a arte dos loucos, mas é no pensamento mítico brasileiro que concentra toda a sua atenção. Péret tenta realizar a viagem prevista entre as comunidades indígenas para entrar em contato direto com seus ritos, sua arte e suas lendas - viagem que somente será efetivada quando de sua segunda vinda ao Brasil, em 1955. Começa a reunir a documentação e o material para seu projeto de uma antologia de contos e lendas indígenas, num contexto em que se manifesta, também no Brasil, um grande interesse pela tradição oral dos índios. Será apenas em 1959, no último ano de sua vida, depois de um longo período no México (onde aprofundará e alargará seu conhecimento do pensamento mítico) e depois de sua segunda estada no Brasil, em 1955-1956 — que Benjamin Péret conseguirá concretizar esse projeto que o tinha acompanhado ao longo de sua vida: sua Antologia dos mitos, lendas e contos populares da América.

Entretanto, já durante o período 1929-1931, Péret descobrirá e poderá estudar de muito perto o pensamento mítico de origem africana, assistindo a numerosas cerimônias de candomblé e macumba nos terreiros do Rio de Janeiro. No início do primeiro artigo (de uma série de 13) que publicou sobre as religiões africanas na imprensa brasileira, ele explica:

"Eu as considerei sobretudo sob o ponto de vista poético, pois, ao contrário do que se passa com as outras religiões mais evoluídas, delas transborda uma

\footnotetext{
${ }^{27}$ PEDROSA, Mário. “As tendências sociais da arte e Käthe Kollwitz”. In: Idem. Arte necessidade vital. Rio de Janeiro: Livraria Editora da Casa do Estudante do Brasil, 1949.

${ }^{28}$ BRETON, André; TROTSKI, Leon. "Por uma arte revolucionária independente". In: FACIOLI, Valentim (Org.). Por uma arte revolucionária independente. Apresentação de Gérard Roche. Tradução de Carmem Sylvia Guedes e Rosa Maria Boaventura. Rio de Janeiro: Paz e Terra/São Paulo: CEMAP, 1985. p. 42-43.

${ }^{29}$ Péret colaborará no último número de La Révolution surréaliste, em fins de 1929, e, a seguir, nos números 1 e 2 de Le Surréalisme au service de la Révolution (O surrealismo ao serviço da Revolução), de julho e outubro de 1930, para os quais enviará poemas vibrantes de revolta e indignação, que farão parte da coletânea Je ne mange pas de ce pain-là (Desse pão, eu não como) e o conto satírico "Morts ou vifs" (Mortos ou vivos), tomando, assim, parte na polêmica aberta pelo Segundo manifesto do surrealismo.
} 
poesia primitiva e selvagem que é quase, para mim, uma revelação."30

Mas "a precisão descritiva de Péret que se situa como um etnógrafo perfeito, retratando com fidelidade os detalhes e os ritmos dos atos", sendo "impressionante como ele conseguiu aquilo que era simbolicamente significativo na cerimônia e o transmitiu ao leitor", leva o professor Clóvis Moura propor uma reedição daquele estudo, por ser "um marco significativo dos estudos afro-brasileiros, levando-se em consideração, inclusive, o seu pioneirismo, pois ele precede a Gilberto Freyre, Artur Ramos, Edson Carneiro e os demais africanistas brasileiros." $" 31$

$\mathrm{Na}$ conclusão da série de artigos, Péret condena o papel castrador e opressor da Igreja Católica, sublinhando o caráter de resistência cultural e social desempenhado pelas religiões negras no Brasil. Seu anticlericalismo militante, cuja radicalidade chocou seus amigos antropófagos, não é o produto de uma pose de parisiense provocador, mas o grito do poeta, para o qual, como escreverá mais tarde, "nos mitos e lendas animistas das primeiras idades fermentam os deuses que vão por na poesia a camisa de força dos dogmas religiosos." 32 Isto é, para Péret,

“[...] se a poesia cresce no rico terreno da magia, os miasmas pestilentos da religião que se erguem a partir deste mesmo terreno estiolam-na, e será preciso erguer bem alto o seu cume, para além da camada venenosa, a fim de a poesia encontrar de novo o seu vigor."33

Péret procura exprimir essa ação poética através da tentativa de realização de um filme no qual o grande palhaço paulista Piolim deveria ser a vedete ${ }^{34}$. Péret o tinha encontrado por ocasião do "Primeiro festim" antropofágico organizado por Oswald de Andrade, no primeiro semestre de 1929. Na sua correspondência, pode-se seguir, passo a passo, seus esforços para conseguir o financiamento para o filme, do qual ele termina o script de 338 cenas, 1500 metros de filme, preocupando-se com os meios técnicos de sua sonorização. Infelizmente nem os patrocinadores contatados, nem a idéia de uma sociedade de subscritores permite seu financiamento. Pior ainda, do script no qual Péret reservou a Piolim "um ministério de primeira ordem", encontramos apenas um fragmento de uma folha inutilizável. Estamos, assim, privados de um filme de Péret onde o espírito de seus contos, muito próximos algumas vezes do verve dos filmes burlescos norte-americanos, teria podido se desenvolver, filme que teria sido o exato contemporâneo de $A$ idade de ouro de Luis Buñuel e Salvador Dalí.

Esse interesse de Péret pelo cinema leva-o a propor, numa reunião da Comissão Executiva da Liga Comunista Brasileira, em $1^{\circ}$ de fevereiro de 1931, a criação de uma cooperativa cinematográfica para a exibição de "filmes revolucionários"; leva-o, também, a assinar um prefácio para um livro de F. Slang, editado em 1931, em São Paulo, $O$ Encouraçado Potemkim, história da revolta da esquadra russa na bahia de Odessa, no ano de 1905, que segue, passo a passo, a ação do filme de Eisenstein.

A recriação e a análise que Péret faz de uma outra revolta de marinheiros — desta vez, em 1910, dos marinheiros brasileiros liderados pelo marinheiro negro João Cândido contra os castigos corporais na esquadra brasileira - precipitam, talvez, as condições de sua prisão e de sua expulsão, em 30 de dezembro de 1931. Com efeito, Péret apaixonou-se pelo movimento conhecido como "A Revolta da chibata" e sobre ele escreveu um livro chamado $O$ Almirante

\footnotetext{
${ }^{30}$ PÉRET, Benjamin. “Candomblê e makumbá, 1”. Diário da Noite, São Paulo, 25.11.1930.

${ }^{31}$ MOURA, Clóvis. "Três vertentes de interesse de um poeta francês sobre o negro brasileiro". Comunicação apresentada na "Semana Surrealista", organizada pela Aliança Francesa de São Paulo, em 1985. Citação feita a partir de uma cópia do original datilografado.

32 PÉRET, Benjamin. "A Palavra a Péret" (Cidade do México, Novembro de 1942). In: PÉRET, B. ; GOMBROWICZ, Witold. Contra os Poetas. Tradução, introdução e notas de Júlio Henriques. Lisboa, Antígona, 1989. p. 51.

33 Ibid.

${ }^{34}$ Não esqueçamos que Péret foi crítico de cinema, no jornal L'Humanité, e foi dos primeiros a ser fascinado, assim como seus amigos surrealistas, não apenas pela obra de Charlie Chaplin, considerada por eles como um gênio, mas por todo o burlesco norte-americano.
} 
Negro. Como diz, em sua comunicação, Clovis Moura:

"O assunto não é apenas político e polêmico: é também perigoso. João Cândido, cognominado de Almirante Negro, é um dos nomes proibidos até hoje na marinha brasileira que se sentiu desprestigiada pelo fato de um simples marinheiro negro ter assumido o comando da esquadra brasileira récem-chegada da Inglaterra, quando a sua oficialidade ainda estava aprendendo com os oficiais ingleses como manejá-la."

Após ter acumulado uma documentação extremamente rica, em particular nos Arquivos Nacionais da Marinha, aos quais, segundo Clóvis Moura, teve acesso, Péret escreve um livro tendo como pano de fundo a luta de classes daquela época e estabelece um paralelo com a revolta do Encouraçado Potemkin. Infelizmente, quando foi preso pela polícia do Rio, em novembro de 1931, a edição inteira do livro foi confiscada e o original desapareceu. Somente quatro folhas do texto foram encontradas pelo pesquisador Dainis Karepovs: testemunham o vigor que deveria ter sido o conjunto da obra, cujo manuscrito estava terminado em setembro de 1931.

Algumas semanas após, um decreto assinado por Getúlio Vargas, no Rio de Janeiro, em 10 de dezembro de 1931, determinava:

"O Chefe do Governo Provisório da República dos Estados Unidos do Brasil, considerando que o francês Benjamin Péret, conforme foi apurado pela polícia desta capital, se tem constituído elemento nocivo à tranqüilidade pública e à ordem social, resolve expulsá-lo do território nacional." 36

\footnotetext{
${ }^{35}$ MOURA, art. cit.

${ }^{36}$ Citado in: SEM AUTOR. "Determinada a soltura do escritor Benjamin Péret". Folha da Manhã, São Paulo, 15.04.1956.
} 